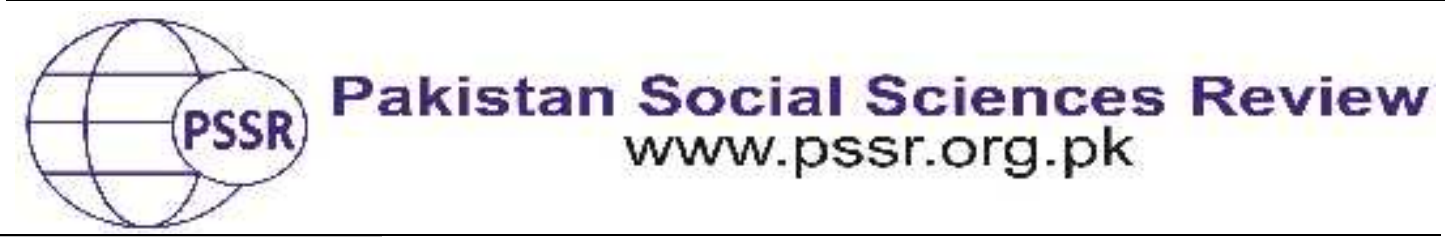

RESEARCH PAPER

\title{
Mentoring for Professional Development: Experiences of University Faculty
}

\author{
Dr. Rukhsana Durrani ${ }^{1}$ Dr. Fouzia Ajmal2 Nosheen Swar ${ }^{3}$
}

1. Lecturer, Department of Early Childhood Education \& Elementary Teacher Education Allama Iqbal Open University Islamabad. Pakistan

2. Assistant Professor, Department of Education, International Islamic University Islamabad, Pakistan

3. Ph. D Scholar, Department of Education, International Islamic University Islamabad, Pakistan

\begin{tabular}{|c|c|}
\hline PAPER INFO & ABSTRACT \\
\hline $\begin{array}{l}\text { Received: } \\
\text { March 21, } 2021 \\
\text { Accepted: } \\
\text { May 01, } 2021 \\
\text { Online: } \\
\text { May 15, } 2021\end{array}$ & $\begin{array}{l}\text { Mentoring means the mutual interaction among the faculty as a } \\
\text { function of professional development. The present research was } \\
\text { carried out to: a) check the extent of mutual interaction between } \\
\text { the mentors and mentees in the department, b) find out the } \\
\text { effectiveness of mentoring in the professional development of }\end{array}$ \\
\hline $\begin{array}{l}\text { Keywords: } \\
\text { Mentee, } \\
\text { Mentor, } \\
\text { Mentoring, } \\
\text { Professional } \\
\text { Development } \\
\text { University Teachers }\end{array}$ & $\begin{array}{l}\text { teachers and c) investigate the benetits / outcomes of mentoring } \\
\text { in the professional development of teachers through formal or } \\
\text { informal way. The population of the study consisted of the } \\
\text { mentors and mentees of public and private universities of } \\
\text { Rawalpindi and Islamabad. For the achievement of the } \\
\text { objectives of the study two questionnaires were designed }\end{array}$ \\
\hline $\begin{array}{l}\text { *Corresponding } \\
\text { Author }\end{array}$ & $\begin{array}{l}\text { separately for mentors and mentees. The data was tabulated, } \\
\text { analyzed and interpreted in the light of the objectives of the } \\
\text { study. Chi square was used as a statistical tool for data analysis. } \\
\text { It is clear from the conclusions that there is no formal or informal } \\
\text { mentoring program in the universities and mentors and mentees } \\
\text { had viewed for a proper mentoring program in the universities. } \\
\text { There is also not any provision of resources for mentoring by the } \\
\text { universities so it is recommended that there should be a formal } \\
\text { and informal mentoring program in the universities as it is very } \\
\text { effective instrument for teaching and the universities may also } \\
\text { provide resources for mentoring. }\end{array}$ \\
\hline
\end{tabular}

\section{Introduction}

Teachers are responsible for broadening the horizon of student's knowledge the development of pupil knowledge, citizenship and moral values. From initial teachers training to retirement, teachers often lack the support and guidance afforded other professionals (Gibson and Blandford, 2005).Newly qualified teachers are regarded competent to teach but their skills are immature and need to be 
nurtured, so mentoring become is an essential part of their professional development.

Mentoring has become increasingly significant as a mode of professional development for teachers in many countries of the world Allen, Singh, and Rowan (2019). It is regarded as an important dimension in the preparation and ongoing development of the teachers and leaders. In mentoring relationship mentors identify new teacher's needs, assess their practice and help them plan improvement that aligns with professional standards. Through mentoring, mentors routinely guide new teachers through reflection that evaluate the effectiveness of their teaching practice on students learning (Grady \& Brock, 2006).The most important task of mentoring is to provide visible signs of support to new teachers during their first year

Mutual interaction and mentoring both play a very important role in the professional development of the teachers. If the experienced teachers guide the newly appointed teachers it would enhance their professional skills and abilities. So this study was designed to evaluate: Mutual interaction and mentoring among the faculty as a function of professional development. Mentoring is very helpful device for professional development. Mentoring helps the mentee to gain and increase his understanding of a discipline or of an organization (Blanco, \&Qualters, 2020).

The purpose of the study was to find out that to what extent mentoring is helpful in the professional development of the teachers. This study will also help to evaluate the present situation of mentoring at higher level and to find out that whether it fulfills the present day needs or not. This study will help to explore the importance of mentoring in the professional development. The study will help to find out the effectiveness of mentoring in teaching and understanding of the educational organization set up. The study may also help the educational administrators and teachers to find out the flaws or weaknesses in the professional development caused by the absence of mutual interaction and mentoring. This study will also be helpful to both mentor (senior faculty members) and mentee (junior faculty members) to know the merits of mentoring for professional development at higher level and may also provide base for further research.

\section{Literature Review}

Mentoring is the process by which an experienced person provides advice, support, and encouragement to a less experienced person. A mentor is a teacher or advisor who leads through guidance and example. Mentoring brings to gather a more knowledgeable professional with a less experienced colleague for collaboration and feedback on teaching and learning (Fied\& Barbara, 1994). Mentors provide support, advice, encouragement and modeling for their mentee, who, in turns, provide mentors with opportunities to use and reflect on their expertise. Mentoring works best when structured and developed overtime. Effective mentoring helps new teachers to become competent classroom teachers, accurate and compassionate 
assessors of student's progress and member of a caring profession (Al Hilali,, Al Mughairi, Kian, \& Karim, 2020)

A mentor provides guidance, wisdom, knowledge and support in a manner in which a mentee can receive it and benefit from it. A mentor is different from a tutor. A tutor specializes in content area support. A mentor develops a relationship with the mentee that provides overall guidance in a field of study or career.In various studies across fields, being mentored has consistently been linked with academic and professional achievement. Mentee gains an increased understanding of a discipline or of an organization. They receive guidance and advice, report higher confidence levels, and gain access to networks and other resources(Bush \&Middlewood, 2005).

According to Bush and Colemans (1995) Effective mentoring reduces professional isolation, provides support and feedback on performance and gives confidence to new teachers during a period of changing and uncertainty.

Different authors described different types of mentoring but two types are most common i.e. formal and informal, however situational mentoring and supervisory mentoring is also used in mentoring programs. Informal mentoring is defined as the relationship created informally without any assistance of the organization. This relationship may initiate by the mentee to seek the guidance or help of the mentor or may arise from the initiative of the mentor, making mentee as a high potential employ. Informal mentoring is that kind of mentoring which also happens in our daily life naturally. Mentors are like the role models for mentees and they follow their behaviors where mentors are not aware that they are following as an example by mentees. An informal mentoring also occur when the knowledge, skills and support are intentionally provided but without the official assistance of the organization. There is not fixed schedule, time table or expectation or regular meetings between mentor and mentee in informal mentoring. Formal mentoring is that types of relationship which is initiated facilitated and supported by the organization in order to give benefit to more employees and participants. The degree of the structure of mentoring depends upon the nature and structure of the organization. However each organization provides the tools to facilitate the participants.

All good supervisors mentor their subordinates to some degree but this is usually restricted to their current job. They mentor them only in problems and in other needs which the subordinates face during their jobs. But due to work load and time constraints they may not give equal time to all of their subordinates which arise the perception of favoritism in the minds of mentees.

Situational mentoring is that type of mentoring relationship in which the right help on the right time is provided by someone when mentees need guidance and advice. The nature of guidance and help depends upon the type of situation mentee facing. This is a short-term mentoring occurs in immediate situations but can 
transition to a more long term connections. It provides moral support and confidence to mentee besides his professional field (Miller, 2002)

Relating behaviors create environments which allow mentors to the understanding of his mentee's ideas, thinking and needs. Mentors establish and maintain a relationship of mutual trust, respect and professionalism with their mentees. He also encourages his mentees to share his ideas with him without any hesitation and reflect upon their experiences which are very essential for the proper functioning of mentoring process.

Assessing mentees plays very important role in the proper functioning of mentoring .Mentors diagnose his mentees and collect data about his ways of learning and teaching. Mentors also find out the competencies of his mentees and determine his skills and confidence that how he handle a given situation .Assessing the behaviors of mentee ensures that his professional needs are identified so that mentoring decisions can be based on the thoughtful considerations from the variety of data.

Coaching of mentee is very essential part of function of mentoring. The professional skills of mentees can be made steadily more effective through mentoring. A mentor tries to help and enhance mentees grasp on subject matter. Coaching enables a mentee to do the optimum and best utilize the existing resources for effective teaching. It also helps the mentee to expand his skills in an effective way for best teaching learning process. Coaching enables mentor to serve as a role model for his mentee in mentoring process as he shares his relevant experiences, examples and strategies with him who open new gates of knowledge for mentee and as a result he also improves his own teaching.

Guiding plays very important role in the functions of mentoring. In this process mentor makes his mentee independent to reflect upon his own decisions and actions, guide and encourage him to construct his own informed teaching learning approaches .Teaching is a process which involves constant decision making. With the help of guidance mentor places the responsibility of decision making with mentee. Guiding skills of mentor include asking the right questions in a right way in a right time. These questions encourage mentee to reflect upon his decisions. Creative and critical thinking are very important functions of mentoring, so guiding empowers mentee to envision future situation, encourage him to take informed risks and help them to build the capacity to develop perceptive decisions and take appropriate decisions. These mentoring functions do not occur in isolation .They consistently overlap and complement each other during the mentoring process. Besides the above functions of mentoring process, it is based on the believes of both mentor and mentee that exploring together with colleagues is essential for professional development (Portner, 2003)

Mentoring is a continuous staff development activity which has the following important elements. 
1. There should be a recognized procedure, formal or informal.

2. A clear understanding of the procedure both by Mentor and mentee and about their role.

3. A relationship based on trust and a good understanding between the two parties.

4. The credibility and genuineness of the mentor as perceived by the mentee.

5. Confidentiality and the quality of good judgment (Ridley \& Brad , 2004).

6. A relationship which is based on the mentee's perceptions of his or her own needs.

7. A suitable range of skills use by the mentor such as counseling, listening, sensitive questioning and analysis.

8. A suitable attitude by both parties such as the ability of mentor to challenge the mentee and self-motivation of the mentee to take action whenever needed and necessary.

9. There should be awareness on the part of both parties necessary for professional development (Gibson \& Blandford, 2005).

The phases of mentoring are described here. Preparing is the first phase of mentoring. The mentor establishes a close relationship based on mutual trust with his mentee whether it is formal or informal mentoring. On this stage the mentor guides the mentee in the preparation of his career advancement and about growth of his profession. The mentee is prepared to enhance his critical thinking and his analytical skills .He gets awareness about the mentoring relationship and of the real motivation in teaching .Both mentee and mentor establishes a learning relationship with each other (Mullen \& Lick, 1999). Negotiating is the $2^{\text {nd }}$ and crucial phase of mentoring. It requires planning the learning goals, constant and desiring outcomes of the partnership. On this phase a number of sensitive issues discussed by both mentor and mentee in individual private talk time and in depth conversations. They share personal hopes, aspirations and goals. Both mentor and mentee negotiate on the process skills which are very important in close mentoring relationship and for professional development (Pete \&.Fogarty, 2007). After negotiating enabling phase starts. During this phase the implementation of mentoring activities take place. Mediate and continuous access to a mentor is very essential on this phase in order to evolve a personal relationship with mentor for participation in activities. During this phase mentor identify the learning needs of mentee and enable him to participate and handle the management, instructional and challenging activities occur during these professional hours. This phase enables mentee to ask for assistance and receives, accepts and applies feedback not only from their mentor but from a variety 
of other sources. It develops the close friendly relationship between the colleagues and they become able to share their ideas and experiences with each other. The mentees enable to welcome to challenging situations and they come to know how to focus on learning and how to grow in their professional fields. Beside it they share and help each other in their daily responsibilities and start work hard for the maximum output. They also set a time for social activities and for the enjoyment of other's company which reduce their tension and burden (Stephens, 1996).

Closure is the fourth and last phase of mentoring relationship. This is the phase in which the relationship between mentor and mentee comes to an end. Both mentor and mentee have shared their experiences and ideas with each other. The most important element in this phase is that, what should be a proper time for closure during mentoring program which depend upon the professional maturity of mentor to recognize the appropriate time for closure. It is the most emotional phase of mentoring because both mentor and mentee get very close to each other and on the stage of departure they feel upset. But anxiety, fear, disappointment and grief should be avoided and the focus should be on professional growth learning, joy and accomplishment (Young, Sheet \& Knight, 2005).

The role and responsibilities of mentor include explaining the policies and procedures of the organization, answering the questions asked by mentee, meeting regularly with new teachers, demonstrating teaching methods, arranging peer observations, solving the problems of new teachers, sharing the knowledge and experiences of teaching methods and materials, encouraging reflection about practice, providing feedback to mentee after observation, offering new ideas and suggestions for the professional growth of mentee, facilitating and assist mentee in teaching process, and bringing purposefully his mentee to the level of professionalism(Siengthai, Pila-Ngarm, \&Sorakraikitikul, 2020).

Effective mentoring helps new teachers to become competent class room teachers, accurate assessors of student's progress and a member of a caring profession of an organization. The following are the characteristics of mentoring. Once mentor and mentee start working relationship, mentor looks at long term as well as immediate personal and professional goals. In a positive working relationship between mentor and mentee, it is helpful for mentor to guide and support the aspirations of mentee. It is good for mentoring relationship to focus on a long term goals but a mentor should not ignore the immediate or short term goals also. Whether the goals are short term or long term, the following key points should be consider while sitting the goals these should be achievable and realistic, measurable in term of quantity, quality or time and both mentor and mentee should agree on goals but it is mentor who initially proposing them (James, 2020).

The main part of mentoring especially working with new teachers is to help them to grow in to their new roles. The success of a mentoring is that, when mentee become comfortable with taking greater control over personal learning experiences. The goal of a good mentoring should be to enable mentee to take initiative boldly even in the absence of their mentors.It is important to listen to mentee carefully in 
order to strengthen mentoring relationship. For effective mentoring it is necessary that let mentees to explain their views, hopes and fears whatever come in their minds and mentors should listen to him carefully. Mentor should not intervene while mentee explaining his ideas.

For effective mentoring it is essential that a mentor share his experiences with mentee and make him to understand that we learn from mistakes so it does not matter if he did any. Mentor should clearly tell the limitations of certain courses of actions to his mentee to avoid the frustration. He should encourage his mentee for creativity. A mentor's job is to find the appropriate balance between supportive, innovative and creative approaches to teaching on the part of mentee and remain honest about limitations (Bagnato, Seo, Salaway, \& Kim, 2016).

In effective mentoring relationship mentors always summarize the discussions and plans with mentee. This procedure ensures the complete understanding of plans and discussions. It is better for mentor to check the shared understanding between himself and his mentee and make the results of mix communication later (Daresh, 2003).

In an article on the benefits of mentoring for professional development the researchers see mentor's primary function as a support for career development and professional development. Some suggestions were given in the article as: If there was no mentor inside the organization then the employee should find it out side of the work place, such as friend, former manager or tutors, because the relationship with them already exists. Mentors and learners should have some common qualities such as honesty, realism and self-awareness. All mentoring relationships have their ended and they can be change with the changing time but it should be replaced by professional contact or by friend (Nankivell, 1997).

Playko (1995) narrated his own experiences as a mentee and mentor and also the benefits of mentoring as he served as both in many organizations. According to the author the greatest benefit of mentoring relationship is the fact that both mentor and mentee feel less isolate as a professional and also make them feel more like a member of a productive and cohesive team. He said that when a system tells you that you have skills and abilities to assist others, it is quite natural that others will think you as a valuable resource, which is very powerful form of professional support. Mentoring relationship gives confidence to mentor and mentee. It also recognized as a very important way to assist the people in becoming more socialized to the new professional role and school organization (Kramer, Hillman, \& Zavala, 2018). According to the author as mentoring is very beneficial for the school leaders but there are some issues which should be take into consideration such as planning of mentoring program, lack of training and appropriate matching of mentor and mentee (Villani\& Danielson ,2002) 


\section{Material and Methods}

The major purpose of the study was to investigate the mutual interaction and mentoring among the faculty as a function of professional development at higher level. It was a descriptive study.

\section{Sample}

Random sample technique was used for the selection of sample and the sample of the study was as follows;

Number of universities $=4$

Number of departments from each university $=4$

Total number of mentors $=28$

Total number of mentees $=32$

\section{Research Instrument}

In order to collect information for the study two questionnaires were designed. One questionnaire was for mentors and other was for mentees. Both questionnaires were structured on three option scales i.e "fully" "to some extent" and "not at all"

\section{Data Collection and Analysis}

The researchers visited themselves to all the sample universities. For this purpose teachers were personally connected in their department of their universities and questionnaires were distributed to them to fillin within a possible short time. For the analysis of data responses of all items were counted and arranged in a tabular form. Chi-Square was used for the analysis of data.

\section{Results and Discussion}

Table 1

Qualification of Mentors and Mentees

\begin{tabular}{cccccc}
\hline \multirow{2}{*}{ Respondents } & & M.A/M.Sc & M.Phil/MS & PhD & Total \\
\hline \multirow{2}{*}{ Mentors } & Response & 1 & 10 & 17 & 28 \\
\cline { 2 - 6 } & Percentage & $4 \%$ & $36 \%$ & $61 \%$ & $100 \%$ \\
\hline \multirow{2}{*}{ Mentees } & Response & 12 & 15 & 5 & 32 \\
\cline { 2 - 6 } & Percentage & $38 \%$ & $47 \%$ & $16 \%$ & $100 \%$ \\
\hline
\end{tabular}

Table No 1 indicates that most (61\%) of the mentors had PhD degree as an academic qualification, while $36 \%$ of the mentors had M. Phil degree as an academic qualification and only $4 \%$ had M.A/M.Sc degree qualification. While most $(47 \%)$ of the mentees had M. Phil degree as an academic qualification; while $38 \%$ had 
M.A/M. Sc degree as an academic qualification and only $16 \%$ had $\mathrm{PhD}$ degree as an academic qualification.

Table 2

Experience of Mentors and Mentees

\begin{tabular}{ccccccccc}
\hline \multirow{2}{*}{ Respondents } & & $\begin{array}{c}\mathbf{0 - 5} \\
\text { years }\end{array}$ & $\begin{array}{c}\mathbf{6 - 1 0} \\
\text { years }\end{array}$ & $\begin{array}{c}\text { 11- } \\
\text { 15years }\end{array}$ & $\begin{array}{c}\mathbf{1 6 - 2 0} \\
\text { years }\end{array}$ & $\begin{array}{c}\mathbf{2 0 -} \\
\text { onwards }\end{array}$ & Total \\
\hline \multirow{2}{*}{ Mentors } & Response & 2 & 12 & 4 & 2 & 8 & 28 \\
\cline { 2 - 9 } & Percentage & $7.1 \%$ & $43 \%$ & $14.2 \%$ & $7.1 \%$ & $29 \%$ & $100 \%$ \\
\hline \multirow{2}{*}{ Mentees } & Response & 26 & 4 & 2 & 0 & 0 & 32 \\
\cline { 2 - 9 } & Percentage & $81.2 \%$ & $13 \%$ & $6.2 \%$ & 0 & 0 & $100 \%$ \\
\hline
\end{tabular}

Table No 2shows that most (92.9\%) of the mentors had above six years' experience while most of the mentees $(81.2 \%)$ had below six years' experience.

Table 3

Designation of Mentors and Mentees

\begin{tabular}{ccccccc}
\hline Respondents & & Lectures & $\begin{array}{c}\text { Assist } \\
\text { Prof }\end{array}$ & $\begin{array}{c}\text { Associ } \\
\text { Prof }\end{array}$ & Prof & Total \\
\hline \multirow{2}{*}{ Mentors } & Response & 0 & 13 & 5 & 10 & 28 \\
\cline { 2 - 8 } & Percentage & $0 \%$ & $46.4 \%$ & $18 \%$ & $36 \%$ & $100 \%$ \\
\hline \multirow{2}{*}{ Mentees } & Response & 32 & 0 & 0 & 0 & 32 \\
\cline { 2 - 7 } & Percentage & $100 \%$ & 00 & 0 & 0 & $100 \%$ \\
\hline
\end{tabular}

Table No 3 indicates that most (46.4\%) of the mentors were Assistant Professors while $36 \%$ were Professors and only 18\% were Associate Professors. Most $(100 \%)$ of the mentees were lecturers.

Table 4

Extent of Mutual Interaction between Mentors And Mentees

\begin{tabular}{cccccccc}
\hline Indicators & & Fully & $\begin{array}{c}\text { To some } \\
\text { extent }\end{array}$ & $\begin{array}{c}\text { Not at } \\
\text { all }\end{array}$ & Total & $\chi^{2}$ \\
\hline $\begin{array}{c}\text { Provision of guidance } \\
\text { at the time of joining }\end{array}$ & Mentor & 14 & 14 & 0 & 28 & $13.98^{* *}$ \\
\cline { 2 - 8 } & Mentee & 11 & 19 & 2 & 32 & $13.6^{* *}$ \\
\hline $\begin{array}{c}\text { Arrangement of the } \\
\text { program }\end{array}$ & Mentor & 3 & 11 & 14 & 28 & $2.33^{*}$ \\
\cline { 2 - 8 } & Mentee & 4 & 9 & 19 & 32 & $10.99^{* *}$ \\
\hline $\begin{array}{c}\text { Positive attitude of } \\
\text { the mentors }\end{array}$ & Mentor & 23 & 4 & 1 & 28 & $30.49^{* *}$ \\
\cline { 2 - 7 } & Mentee & 16 & 15 & 1 & 32 & $13.2^{* *}$ \\
\hline $\begin{array}{c}\text { Mentoring program in } \\
\text { the University }\end{array}$ & Mentor & 21 & 6 & 1 & 28 & $23.2^{* *}$ \\
\cline { 2 - 7 } & Mentee & 25 & 7 & 0 & 32 & $31.38^{* *}$ \\
\hline $\begin{array}{c}\text { Showing friendly attitude } \\
\text { towards mentees }\end{array}$ & Mentor & 25 & 3 & 0 & 28 & $39.92^{* *}$ \\
\hline & Mentee & 16 & 15 & 1 & 32 & $13.26^{* *}$ \\
\hline Guidance by the & Mentor & 22 & 6 & 0 & 28 & $27.71^{* *}$ \\
\hline
\end{tabular}




\begin{tabular}{ccccccc}
\hline mentors & Mentee & 16 & 13 & 3 & 32 & $8.73^{* *}$ \\
\hline $\begin{array}{c}\text { Allocation of } \\
\text { resources by the } \\
\text { University }\end{array}$ & Mentor & 4 & 11 & 13 & 28 & $4.77^{*}$ \\
\cline { 2 - 7 } & Mentee & 5 & 15 & 12 & 32 & $4.95^{*}$ \\
\hline
\end{tabular}

**Significance $\quad \mathrm{df}=2 \quad$ Table value at $0.05=5.99$

Table 4 indicates that the calculated value for mentor was found to be 15.4 and for mentee 10.8, which are greater than the table value at 0.05 , which means that mentors enhanced the critical thinking of mentees. Mentors say they did not arrange mentoring program for new teachers where as mentee reported that mentoring was held. The attitude of mentors was positive during mentoring. Proper mentoring program in the universities is the appropriate method for the guidance of mentees. The data reflected that the mentors had shown friendly attitude whenever they guided their mentees. The guidance of the mentees in facing the problems was carried out by the mentors. University did not provide resources for the guidance of mentees.

Table 5

Improvement of skills

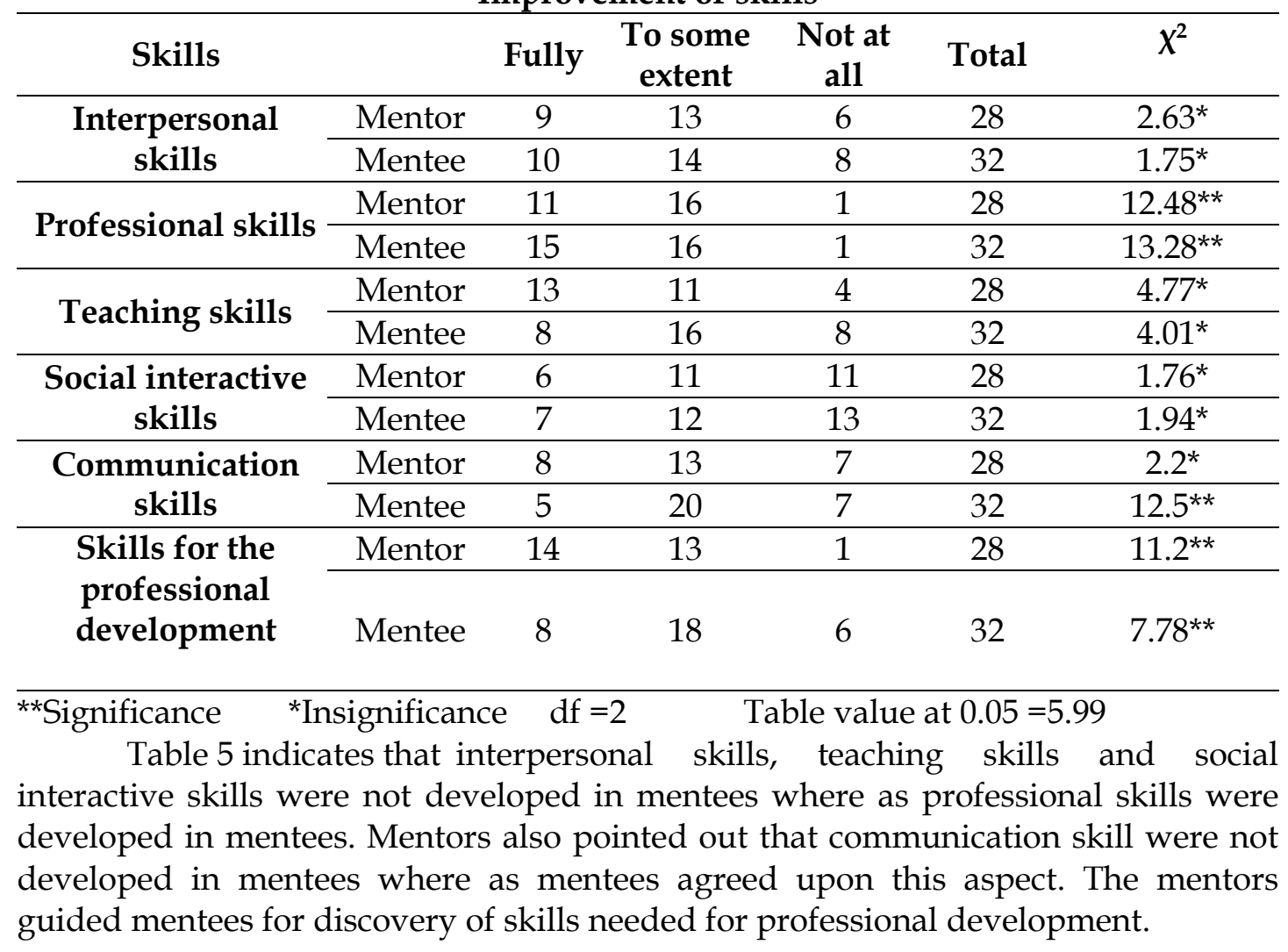


Table 6

Benefits of Mentoring for the Professional Development

\begin{tabular}{|c|c|c|c|c|c|c|}
\hline Indicators & & Fully & $\begin{array}{c}\text { To some } \\
\text { extent }\end{array}$ & $\begin{array}{c}\text { Not at } \\
\text { all }\end{array}$ & Total & $x^{2}$ \\
\hline \multirow{2}{*}{ Identification of abilities } & Mentor & 10 & 14 & 4 & 28 & $5.41^{*}$ \\
\hline & Mentee & 5 & 20 & 7 & 32 & $12.5^{* *}$ \\
\hline \multirow{2}{*}{$\begin{array}{l}\text { Help for up-to-date in } \\
\text { teaching techniques }\end{array}$} & Mentor & 7 & 13 & 8 & 28 & $2.2^{*}$ \\
\hline & Mentee & 8 & 16 & 8 & 32 & $4.01^{*}$ \\
\hline \multirow{2}{*}{$\begin{array}{l}\text { Development of sense of } \\
\text { professionalism }\end{array}$} & Mentor & 15 & 12 & 1 & 28 & $11.63^{* *}$ \\
\hline & Mentee & 11 & 14 & 7 & 32 & $2.32^{*}$ \\
\hline \multirow{2}{*}{$\begin{array}{l}\text { Checking the professional } \\
\text { proficiency }\end{array}$} & Mentor & 9 & 11 & 8 & 28 & $0.48^{*}$ \\
\hline & Mentee & 6 & 15 & 11 & 32 & $3.82^{*}$ \\
\hline \multirow[t]{2}{*}{ Guidance for class teaching } & Mentor & 8 & 18 & 2 & 28 & $13.98^{* *}$ \\
\hline & Mentee & 8 & 18 & 6 & 32 & $7.78^{* *}$ \\
\hline \multirow{2}{*}{$\begin{array}{l}\text { Effective instrument for } \\
\text { teaching }\end{array}$} & Mentor & 14 & 13 & 1 & 28 & $11.2^{* *}$ \\
\hline & Mentee & 22 & 10 & 0 & 32 & $22.89 * *$ \\
\hline \multirow{2}{*}{$\begin{array}{l}\text { Developing good } \\
\text { relationship with } \\
\text { colleagues }\end{array}$} & Mentor & 14 & 9 & 5 & 28 & $4.34^{*}$ \\
\hline & Mentee & 13 & 13 & 6 & 32 & $3.07^{*}$ \\
\hline \multirow{2}{*}{$\begin{array}{l}\text { Encouragement for the } \\
\text { professional development }\end{array}$} & Mentor & 15 & 12 & 1 & 28 & $11.63^{* *}$ \\
\hline & Mentee & 11 & 18 & 3 & 32 & $10.61^{* *}$ \\
\hline
\end{tabular}

It is clear from the table 6 that mentor did not provide support to mentees for the identification of abilities needed for professional development where as mentees reported that support was provided to them for the identification of abilities needed for professional development. Mentors did not provide help for up-to-date in teaching profession to mentees. Although mentors claimed that they had provided sense of professionalism but mentees reported that help for developing sense of professionalism was not provided by mentors. Mentors did not check the professional proficiency of mentees during mentoring. Guidance for class teaching was provided by the mentors. Mentoring is an effective instrument for teaching. It is clear from the above table that mentors did not carried out guidance of the mentees in developing good relationship with colleagues. Mentors had provided encouragement for professional development to mentees.

\section{Conclusion}

Mentors say they did not arrange mentoring program for new teachers where as mentee reported that mentoring was held. The attitude of mentors was positive during mentoring. Proper mentoring program in the universities is the appropriate method for the guidance of mentees. Same sort of results have been mentioned by McConnell, Geesa, and Lowery (2019). The data reflected that the mentors had shown friendly attitude whenever they guided their mentees. The guidance of the mentees in facing the problems was carried out by the mentors. University did not provide resources for the guidance of mentees and it is mentioned by Barrett., Mazerolle, \& Nottingham (2017) also. 
Interpersonal skills, teaching skills and social interactive skills were not developed in mentees where as professional skills were developed in mentees. Mentors also pointed out that communication skill were not developed in mentees where as mentees agreed upon this aspect. The mentors guided mentees for discovery of skills needed for professional development.

The mentor did not provide support to mentees for the identification of abilities needed for professional development where as mentees reported that support was provided to them for the identification of abilities needed for professional development. Mentors did not provide help for up-to-date in teaching profession to mentees. Although mentors claimed that they had provided sense of professionalism but mentees reported that help for developing sense of professionalism was not provided by mentors. Mentors did not check the professional proficiency of mentees during mentoring as mentioned by Schriever and Grainger (2019). Guidance for class teaching was provided by the mentors. Mentoring is an effective instrument for teaching. However mentors did not carried out guidance of the mentees in developing good relationship with colleagues although it has been mentioned as an important aspect by Paula and Grīnfelde (2018). Mentors had provided encouragement for professional development to mentees which is in line with the results of Malin and Hackman (2018).

\section{Recommendations}

1. It is clear from the conclusions that there is no formal or informal mentoring program in the universities and mentors and mentees had viewed for a proper mentoring program in the universities. There is also not any provision of resources for mentoring by the universities so it is recommended that there should be a formal and informal mentoring program in the universities as it is very effective instrument for teaching and the universities should also provide resources for mentoring.

2. The skills such as inter-personal skills, social interactive skills and communication skills are very important for the professional growth and development but they were not improved by mentors in mentees so it is recommended that mentors should improve the skills needed for professional development such as inter personal skills, social interactive skills and communication skills.

3. The mentors did not help mentees in developing good relationship with their colleagues therefore it is suggested that mentors should help mentees in developing good relationship with their colleagues as it is very important for continues professional development.

4. Mentors did not arrange program for the guidance and adjustment of mentees and also did not develop talent and abilities of mentees needed for their professional development therefore it is recommended that mentors should plan a proper program for the guidance and adjustment of mentees in the university and also explore their talent and abilities needed for professional development. 


\section{References}

Al Hilali, K. S., Al Mughairi, B. M., Kian, M. W., \& Karim, A. M. (2020). Coaching and Mentoring. Concepts and Practices in Development of Competencies: A Theoretical Perspective, International Journal of Academic Research in Accounting, Finance and Management Sciences, 10 (1): 41-54 (DOI: 10.6007/IJARAFMS/v10i1/6991)

Allen, J., Singh, P., \& Rowan, L. (2019). Professional experience in initial teacher education: keeping abreast of change in the 21st century , Asia-Pacific Journal of Teacher Education, 47:4, 323-326, DOI: 10.1080/1359866X.2019.1637599

Bagnato, S. J., Seo, J. W., Salaway, J., \& Kim, M. S. (2016). Field-validation of the COMET mentoring model to enhance the instructional practices of head start teachers. Perspectives, 1(1).

Barrett, J. L., Mazerolle, S. M., \& Nottingham, S. L. (2017). Attributes of effective mentoring relationships for novice faculty members: Perspectives of mentors and mentees. Athletic Training Education Journal, 12(2), 152-162.

Blanco, M. A., \&Qualters, D. M. (2020). Mutual mentoring: Effect on faculty career achievements and experiences. Medical Teacher, 1-7.

Bush, T. and D. Middlewood. (2005), Leading and Managing People in Education, Sage publications limited, London.p.22-23.157-169.

Coleman.M and T.Bush.(1995). Professional development for heads: the role of mentoring, Journal of Education Administration, 33(5)

Daresh,C.J.(2003),Teacher Mentoring Teachers, A practical approach to helping New and Experienced Staff, Corwin Press,California.p23-49.

Fied, T. and Barbara.(1994). Teachers as Mentors: A practical guide, Routledge. Great Britin.

Gibson's. ands.Blandford.(2005). Managing Special Educational Needs, A practical guide for primary and secondary schools, Paul Champan publishing ,London.p.127-137.

Grady, L.M. and B. L. Brock. (2006). Developing a Teacher Induction Plan, Corwin Press, California, p.74-119.

James, S. M. (2020). Mentoring for effective literacy teaching: Australian preservice teacher's perspectives (Doctoral dissertation, Southern Cross University).

Kramer, D., Hillman, S. M., \& Zavala, M. (2018). Developing a culture of caring and support through a peer mentorship program. Journal of Nursing Education, 57(7), 430-435. 
Li, S., Malin, J. R., \& Hackman, D. G. (2018). Mentoring supports and mentoring across difference: insights from mentees. Mentoring $\mathcal{E}$ Tutoring: Partnership in Learning, 26(5), 563-584.

McConnell, K., Geesa, R. L., \& Lowery, K. (2019). Self-reflective mentoring: Perspectives of peer mentors in an education doctoral program. International Journal of Mentoring and Coaching in Education.

Miller.A,(2002). Mentoring students and young people:A hand book of effective practice, Koganpage, London

Mullen, A.C. \& D.W.Lick (1999). New directions in mentoring, Falmer press, London, p.34-35, 74-103,137-141,188-196.

Nankivell.C. \& Shoolbred.M,(1997). Mentoring: a valuable tool for career development, 5(3), Librarian Career Development ,MCB University press.

Paula, L., \&Grīnfelde, A. (2018). The role of mentoring in professional socialization of novice teachers. Problems of Education in the 21st Century, 76(3), 364.

Pete, B.\& R.Fogarty (2007), From Staff Room to Classroom, Corwin Press, California.p. 143-147.

Playko.A.M, (1995). Mentoring for educational leaders: a practitioner's perspective, Journal of Educational administration, 33(5)

Portner, H. (2003).Mentoring new teachers, Crown Press, Inc, California, p.2-67.

Ridley, R.C. \& W.J.Brad (2004), The Elements of Mentoring, Palgrave Macmillan,USA.

Schriever, V., \& Grainger, P. (2019). Mentoring an early career researcher: insider perspectives from the mentee and mentor. Reflective Practice, 20(6), 720-731.

Siengthai, S., Pila-Ngarm, P., \&Sorakraikitikul, M. (2020). How Mentors and Protégés Perceive and Practice mentoring in Thailand. In Mentorship-driven Talent Management. Emerald Publishing Limited.

Stephens, P. (1996). Essential Mentoring Skills: A Practical Guide Book for School Based Teachers Educators, Nelson Thorns.

Villani.S. \& C. Danielson (2002), Mentoring Programs for New Teachers, Corwin Press, United States.

Young, G.P, \& J.M.Sheet. and D.D.knight (2005), Mentoring Principals, Crown Press, California, p. 103.3-14.20-23. 